\title{
DRAMSKO STVARALAŠTVO NEDŽADA IBRIŠIMOVIĆA KAO REFLEKSIJA ODBLJESAKA VARIJABILNE OPĆELJUDSKE PROŠLOSTI
}

\section{Sažetak}

Dramski opus Nedžada Ibrišimovića omeden je i determiniran historijom kao vječitom inspiracijom koja svoje izvore crpi iz bogate i plodne bošnjačke sredine, ali je značajno, čak i neophodno, spomenuti i to da su njegovi dramski tekstovi satkani na temama koje je on uglavnom već umjetnički zahvatio $i$ obradio u svom opsežnom romanesknom i pripovjedačkom radu. Historija, kod Ibrišimovića, nije definirana kroz tradicionalnu definiciju koja svoju polaznu tačku uvijek utemeljuje na nekom značajnom historijskom dogadaju ili na nekoj znaćajnoj historijskoj ličnost, pa je zbog toga osudena da ima retrospektivnu tačku gledista. Nasuprot tome, Ibrisimović historiju definira onako kako je to započeo Niče, a kasnije su mnogi pribvatili tu definiciju historije kao varijabilnog zbira historije mentaliteta, pri čemu se ona nužno mora sagledavati kao "živo" stvaralačko tkivo, dual sadašnjosti i budućnosti $i$ upravo zbog toga je najvažnije spoznati ovu psihološku stranu historije, kao eksplicitni pokazatelj "historije odozdo". Njegova koncepcija prošlosti koja izričito uobličuje njegov stvaralački rad je takva da on uvijek teži da egzistencijalnim odbljescima varijabilne prošlosti pronade ono što je univerzalno, ono što kao neizlječiva kletva odrectuje cjelokupno čovječanstvo od njegova postanja, pa tako, iznova i iznova, u starom traži novo, poznato želi učiniti spoznatim, u pojedinačnom traži općeljudsko koje je nužan cilj svakog istinskog umjetničkog stvaralaštva.

Ključne riječi: Nedžad Ibrišimović, historija, tok svijesti, varijabilna prošlost, vrijeme, općeljudsko, slutnja, muftija Karabeg, Husein beg Gradaščević, Zmaj od Bosne, Boja Hrde, bošnjačka književnost, dramska književnost, teatar apsurda, historijska drama

Dramski opus Nedžada Ibrišimovića uglavnom je omeđen i determiniran historijskom inspiracijom koja svoje izvore crpi iz bogate bošnjačke sredine, ali je značajno, čak i neophodno, spomenuti i to da su njegovi dramski tekstovi satkani na temama koje je on uglavnom već zahvatio i obradio u svom opsežnom romanesknom i pripovjedačkom 
radu. Njegova koncepcija prošlosti koja izričito uobličuje njegov stvaralački rad je takva da on uvijek teži da egzistencijalnim odbljescima varijabilne prošlosti pronađe ono što je univerzalno, ono što kao neizlječiva kletva određuje cjelokupno čovječanstvo od njegova postanja, pa tako, iznova i iznova, u starom traži novo, poznato želi učiniti spoznatim, u pojedinačnom traži općeljudsko koje je nužan cilj svakog istinskog umjetničkog stvaralaštva. Inspiriran vlastitim romanom, Ibrišimović je napisao izvrstan neoekspresionistički dramski tekst (1970) o porodici Abazović. Kao i u romanu, koji je antologijski primjerak romana toka svijesti u bosanskohercegovačkoj književnosti, osnovni tok dramske radnje nam se nudi na recepciju kroz viđenja i odbljeske pomućene svijesti "kopileta"-ugursuza, nijemog Muzafera, vanbračnog, odbačenog i nepriznatog sina moćnog i uglednog Ihtara Abazovića i poluciganke, polulude Nurke koja kao sablasna sjena kruži po Herdekovcu.

Historija kod Ibrišimovića nije definirana kroz tradicionalnu definiciju koja svoju polaznu tačku uvijek utemeljuje na nekom značajnom historijskom događaju ili na nekoj značajnoj historijskoj ličnost, pa je zbog toga osuđena da ima retrospektivnu tačku gledišta. Nasuprot tome Ibrišimović historiju definira onako kako je to započeo Niče, a kasnije su mnogi prihvatili tu definiciju historije kao zbira historije mentaliteta, pri čemu se ona nužno mora sagledavati kao stvaralačko tkivo sadašnjosti i budućnosti i upravo zbog toga je najvažnije spoznati ovu psihološku stranu historije.

O tome, uvaženi književni teoretičar i kritičar, Enver Kazaz kaže:" ... Ibrišimović historiju koristi samo kao nužan ambijent za priču o drami identiteta, svijesti $i$ savjesti $i$ jezika/gledanja kojima se ta drama izražava, pa se namjesto historijske faktografije u njegovim romanima povijest ispoljava u formi metaforičke $i$ paraboličke sadržine. Otud $i$ Ugursuz i Karabeg i Braća i veziri razvijaju onaj koncept povijesti što ga je Niče definirao kao kritički koncept, dakle, u kojem se povijest sagledava iz perspektive sadašnjosti i budućnosti, pošto je u njihovoj službi, pa iz toga proizlazi ispitivanje psihološke sadržine povijesti, odnosno povijesti mentaliteta. ${ }^{\prime 1}$

\footnotetext{
${ }^{1}$ Enver Kazaz: Bošnjački roman XX vijeka, Naklada ZORO, Zagreb-Sarajevo, 2004, str. 314.
} 
Ovakav koncept vremena Ibrišimović prenosi i na svoje dramske tekstove, pa tako Muzafer, kao i u romanu opsesivno i prokleto traga za svojim mutnim porijeklom i pokušava shvatiti način života kojim na Heredekovcu žive Abazovići, ogrezli u atmosferi patoloških i "pomjerenih" strasti, nasilja, mržnje, i nekog neobjašnjivog zlosutnog predosjećanja zla i nesreće koji ih vodi u fatalističku propast. Njegovo traganje za vlastitim identitetom ne dešava se na uobičajeni racionalni način, jer put koji je determiniran uzročno-posljedičnom kauzalnostima, nije ono što se uklapa u definiciju historije koja je ovdje predstavljena.

Nasuprot takvom racionalnom slijedu vlastite potrage, Muzafer do svog identiteta dolazi (ili ne dolazi) preko mutnih i konfuznih odbljesaka svoje uzavrele svijesti, pa prema tome potvrđuje i sam koncept historije koji Ibrišimović propagira, a to je onaj da historija (samim tim i sveobuhvatno vrijeme) nije ništa drugo nego konfuzni i varijabilni skup isprepletenih i zamršenih stanja svijesti (egzistencijalnih stanja), koji se kroz takvo djelovanje pretvara u svevrijeme.

Život Abazovića je potpuno ogoljen, on protiče $u$ iskonom grijehu, ispunjen je animalnim porivima, nema nikakvih odbljeska radosti i naprosto se utapa u nečistoj krvi, u titrajima prokletih gena, neizgovorenih riječi, $u$ neartikulisanom kriku i u statičnom i nerazumnom ćutanju. Muzafer je bezuspješan u svojoj potrazi za porijeklom koje bi mu trebalo donijeti sreću, jer u njegovom porijeklu leži prokletstvo koje mu onemogućava spoznaju sreće, a koje svoj korijen ima $\mathrm{u}$ iskonskim grijesima koji su postali sastavni dio svih Abazovića: sodomija, patološki poroci, fatalna opsjednutost bludom i razvratom, strahom od neizvjesnosti, i onim nekim sveprisutnim zlom koje je tu samo da njih uništi ("slutnja").

Ovdje se opet moramo vratiti Ničeu koji je od cjelokupne ljudske povijesti, upravo borbu morala protiv osnovnih životnih instinkta označio kao ono najnemoralnije u ljudskoj povijesti. Po toj percepciji, sam Muzafer upravo i jeste najveći ugursuz od svih Abazovića, koji su iako ogrezli u grijehu, prestali da se bore. Degenerirani životi prošlih i sadašnjih Abazovića, silnika Ihtara, njegovih žena, Altune i Nizame, sinova Malika, Džafera, Kemala, njihovih žena Kadife, Safije i Begzade, ajana Abdurahmana, nesretne ciganke Nurke, žigosat će i nesretnog Muzafera, koji se u svojoj pomućenoj svijesti prisjeća i svog, 
ali i tuđih rađanja, te poput sablasti jezivo lebdi nad Herdekovcem $u$ potrazi za životnim smislom, ali on uskoro, čim mu se svijest razbistri, ostaje bez nade da će se Abazovići ikada osloboditi mitskog i fatalističkog nasljeđa grijeha. Čak i u onom naizgled sretnom trenutku, kada Ugursuz iznenada dobiva moć govora, teška sjena zla i nečovještva ne napušta porodicu.

Muzafer, koji je i sam bio žrtva (plod) grijeha, kad stiče moć govora, postaje novi Abazović, ulazi u život kao potencijalni počinitelj grijeha i tek tada shvata da mu je blagoslov povratka moći govora i bistrenja svijesti, ukazan samo zbog toga da postane potpuno svjestan besmislenosti svoje egzistencije, te definitivno odbija da bude čovjek pod takvim uslovima. On shvata da ga je "slutnja" do tad zaobilazila jer je bio "pomjeren" i radije bira svoju "pomjerenost" nego spoznaju da je i sam tipični Abazović. Scene njegove tragične spoznaje su isprepletene, od neartikuliranih krikova kojima se Muzafer želi vratiti svojoj "pomjerenosti" i od mase bolnih negacija abazovićevskog bitka:

"MUZAFER: (Prilazi kadiji. Njegove riječi se teško razumiju izgovarane muklim neprirodnim glasom) Ne...nisam im brat... niiisssammm... iiim brat... Ja nisam Abazović ...laž, kadiiida... Kadija...! Kaaaaaa...! Nisam... Neću ništa... ništa. Ništa... (osluškuje svoj glas) Ništa... Nisam Abazović... To je gospodar... Smrt... Slutnja..."

"MUZAFER: ... Jasno razabirem stvari i čujem sebe kako govorim, ali kao da je ovo neko drugi... (zgrči se i pada na koljena, neartikulisan uzvik) Aaaaaaa...! Slutnja neće pomjerene... Ni ja joj nisam izmakao... I mene je dokopala........"

"NURKA: Zašto odričeš da si Abazović? Odgovori... Otrova ću ti dati ako ne odgovoriš...

MUZAFER: Slutnja... Slutnja... Dokopaće me slutnja, zlo... Pašću... Pamet...!" 4

\footnotetext{
${ }^{2}$ Nedžad Ibrišimović, Ugursuz, Narodno pozorište Tuzla, str. 77.

${ }^{3}$ Ibid., str. 89.

${ }^{4}$ Ibid., str. 82.
} 
Ovaj dramski tekst ima dosta proznih elemenata, jer u biti funkcionira na tipični "ibrišimovićevski" prozni način pripovijedanja (bildungsromani), kroz odbljeske razbijenih dramskih slika (scena) koje postepeno dobivaju na intenzitetu značenja i pred kraj drame se pretvaraju u svojevrsnu značenjsku eksploziju.

Upravo zbog toga, Josip Lešić za ovu dramu kaže:"...radnju ove "bildunsgdrame", i inače razbijene u niz diskontinuiranih slika, oduzimajući joj ono neophodno logično (i detaljno motivirano) dramsko uporište i svodeći je na krhotine i parčad razbijenog ogledala u kojima se vide odbljesci događanja ali se ne odražava jasna i cjelovita slika."

Drama obiluje prenapregnutom atmosferom tamnog vilajeta iskazanog u naboju silnica prekomjerne čulnosti, mračnih predskazanja koja reflektuju fatalističku slutnju i prijeteći lebdi nad svim likovima koji su kažnjeni svojim abazovićevskim porijeklom. Ma koliko se činilo da je Herdekovac samo i isključivo vezan za određeno vrijeme i određene ljude, u čemu nas može zavarati, istina ne tako jasno označeni, historijski okvir drame, koji se može samo nazrijeti i Ibrišimović ga nije ni odredio precizno, jer mu to nije ni bio cilj. Herdekovac je u biti metafora za svijet u cjelini, svijet sa svim njegovim rugobama, izopačenostima i bolestima, ali i sa njegovim začuđujućim ljepotama koje je teže pojmiti i obuhvatiti, nego samu pomjerenost. Jednako kao što se isključivo sluti zlo, nikad dobro.

Likovi gotovo i nisu definirani u smislu tipične dramske karakterizacije, nego su više simboli svojih strasti koje su dovedene do krajnjih tačaka. Slutnjom, kao prokletstvom, obuzet je cijeli svijet, ne samo Abazovići $\mathrm{u}$ nekom pretpostavljenom vremenu tridesetih godina XIX stoljeća (doba reformi sultana Mahmuta II). Slutnja se obistinjuje na različite načine, da bi svoje konačno uobličenje dobila u Muzaferu.

U drami Karabeg (1983.), Ibrišimović je pokušao da dramski oživi jedan od najtežih prijelomnih trenutaka u bosanskohercegovačkoj historiji, kada se smjenjuju dva velika carstva, osmansko i austrougarsko. Kao mjesto lokaliziranja dramske radnje on uzima grad

5 Josip Lešić, Dramska književnost II, Institut za književnost/Svjetlost, Sarajevo, 1991, st. 208. 
Mostar i pokušava da putem slike mikrokozma (Mostara) prikaže dramatičnost takve slike i onog strašnog kulturalnog šoka koji ona izaziva. Dramski tekst je nastao na osnovu mnogobrojnih dokumenata, memoara i zapisa, ali je najveći dio historijskih informacija koje je utkao u dramu, Ibrišimović pronašao u kratkotrajnoj historiji "Hamzićevog carstva", kako je on nazvao prijelomni i prijelazni trenutak davne 1878. godine u Mostaru, kada dolazi do potpune anarhije koja se manifestirala u nasilju, neredima, bezvlašću, ali i onom egzistencijalnom iščekivanju i zapitkivanju, šta i kako dalje, da li se dići na oružje i uprkos sultanovoj fetvi, oduprijeti se "kaurima", ili se pokoriti odlukama tada nadmoćnih svjetskih sila (prihvatiti činjenicu da je sultan prodao Bosnu na Berlinskom kongresu) i pokorno dočekati da "kaurska" vojska okupira Mostar, bez trunka otpora.

S takvom dilemom se borio Karabeg, stvarni povijesni lik iz Mostara, najmlađi muftija koji je po svome znanju i stručnosti bio jako cijenjen u svoje doba. Karabeg je iz historije ušao u literaturu u formi priče, romana i drame, a takav život u umjetnosti udahnuo mu je Nedžad Ibrišimović. Njega razdire unutrašnja dilema koju ne može nikom da objasni, da iskaže i da natjera ljude oko sebe da spoznaju njegove muke, pa čak ni svom najbližem prijatelju Kasimu koji utočište od svih ovozemaljskih problema traži u opijumu i stihovima.

"KARABEG: ...Pretežnoj sili se ne možemo oduprijeti i ja ne znam kako to ne uvidate... Opremo li se oni će udariti, udare li, grad će uništiti i spržiti i pri tome nećete stradati samo vi nego će i mnogi drugi uludo izginuti. Ne bigarji hak. Svrhu nećemo postići nikakvu...Da sve žrtvujemo što imamo $i$ da svi izginemo do jednog sudbinu Bosne $i$ Hercegovine u ovom času nećemo izmijeniti ni za dlaku. I ja ne znam kako to vi ne vidite.... Ovaj rat nije farz, Allah nam ga zabranjuje. ${ }^{\prime \prime 6}$

Međutim, Lešić ovu dramu ocjenjuje kao historijsku dramu koja fragmentarno, više ili manje uspješno, ilustrira događanja, poprimajući osobine hronike, ali koja nije uspjela da tim događajima da jedno univerzalnije umjetničko i filozofsko viđenje kulturalnog šoka pri ugrožavanju ili promjeni uslova ljudske egzistencije. Iako su odnosi između dramskih junaka gotovo neizdiferencirani (Karabeg-Kasim),

\footnotetext{
${ }^{6}$ Nedžad Ibrišimović: Karabeg, Drame, "Veselin Masleša", Sarajevo, 1988, str. 80.81.
} 
bez neke kompleksnije i dramatičnije dileme glavnog junaka, bez katarze na kraju i bez precizno oblikovanih likova (Kasim), dramski dijalog je jako interesantno oblikovan sa stilističkog aspekta, imamo raspodjelu proznog i stihovnog dijaloga. Lik Kasima nije precizno oblikovan, osim što je definiran kao opijumski ovisnik, ali je njegov govor više (gotovo sav) u stihovnom, nego u proznom obliku, i autor mu pridaje stihove iz Bulbulistana. Samim tim je njegov govor stilistički znatno markiran u odnosu na ostali dramski tekst i on intertekstualno upliće u ovaj Ibrišimovićev dramski tekst najljepše bisere bošnjačke osmanlijske književnosti, posebno ističući one stihove koji tematiziraju pojmove odanog prijateljstva i čovječjeg morala.

"KASIM: Iskusiti rastanaks prijateljima je znak pakla. Neka me Bog sačuva, pogriješio sam. Pakao je njegov zna! Koliko će me plašiti užasom sudnjeg dan! Po mome mišljenju, sudnji dan je rastanak sa prijateljima. U nepotrebnosti sastanka ne budi siguran po običaju rastanka jer ako ti sudbina ponudi kakav napitak, otrov je u pitanju. Uskrsnuće, o Azeri, u društvu sa prijateljem ima veću čast od raja. Kada se udalji prijatelj od prijatelja, tada je sudnji dan. ${ }^{\prime 7}$

Ponegdje se mogu zapaziti elementi gega i lakrdije (Kuduz-beg na Zejni, IV).

"ZEJNA: De, silazi...

KUDUZ: Nisam gotov...!

ZEJNA: Pa zar ti baš nikako ne znaš misliti nego na meni...?

KUDUZ: A Karabeg, njemu ne znam šta bih učinio, ali ženo, kunem ti se, samo što pomislim na njega podilaze me slatki srsi baš kao kad tebe dotaknem...!

ZEJNA: I ti to meni kazuješ, gade... Silazi.

KUDUZ: Njemu bih glavu otkinuo, ali ženo, kunem ti se, samo što bih mu je otkinuo, uzo bih je u obje ruke i izljubio... Vradžbine su pri njemu, kao da omanđija... Mrtva bih ga izljubio... Ali ovo što narod od bune

${ }^{7}$ Ibid., str. 63 . 
odvraća i priča okolo da mi lažemo, a da samo on istinu govori ta, ta će mu biti posljednja, ili se ja neću zvati Kuduz-beg." ${ }^{18}$

Zbog svih nabrojanih nedostataka Josip Lešić ovaj dramski tekst ocjenjuje kao dramsku hroniku o jednom prijelomnom i sudbonosnom historijskom vremenu, ali mu ne pripisuje neke visoke umjetničke vrijednosti.

Odlukama Berlinskog kongresa i nametanju Austro-Ugarske vlasti Bosni i Hercegovini domaći narod u cijeloj zemlji, a posebno u Hercegovini se želio suprotstaviti oružanim putem, ali se nije usuđivao krenuti u borbu bez dozvole lokalnih vjerskih poglavara. Karabeg je kao dubokouman i nadasve razuman čovjek procijenio da domaći narod u oružanoj borbi nema nikakve šanse pred mnogo jačom i organizovanijom Austro-Ugarskom vojskom, te je odbio da donese traženu fetvu.

Odbijanje Karabega da donese ovakvu fetvu izazvalo je bijes ratnim pokličima zaluđenog naroda i donesena je odluka da ukoliko narodni poglavari, kako politički tako i vjerski, ne žele odobriti borbu, da prvo njih treba smaknuti i tek onda krenuti u borbu. Tako je u noći s petka na subotu 2. augusta 1878. donesena odluka da se muftija i još četvorica gradskih čelnika sprovedu u kasarnu Konak koja se nalazi na lokaciji Suhodolina i da tu budu ubijeni, te je naša historija tako zabilježila da je na barbarski i potpuno zvjerski način ubijen jedan od najvećih intelektualnih predstavnika tog vremena.

Poslije saznanja da okupacione trupe nastupaju prema Mostaru, pred Konakom se okupila velika masa naoružanih ustanika, kojoj se obratio Ali-efendija Haljevac sa obavještenjem da je od strane vodstva ustanika u zemlji imenovan vođom otpora za područje Hercegovine. Tom prilikom su svrgnuti Komandanpaša i mostarski mutesarif Mustafapaša, a na Tabiji je, pored osmanlijske, izvješena i ustanička zastava, što je bio znak preuzimanja vlasti. Vođe otpora su se potom okupile u Konaku, te su, svjesni činjenice da nemaju dovoljno vojnih stručnjaka za uspješno vođenje ratnih operacija, ponudili pojedincima iz stare vlasti da se stave na čelo pokreta. Muftija Karabeg je odbio ponudu da preuzme vojno zapovjedništvo, pa je predložio svrgnutog mutesarifa,

${ }^{8}$ Nedžad Ibrišimović, Karabeg, Drame, "Veselin Masleša", Sarajevo, 1988, str. 63. 
koji također nije prihvatio ovu dužnost, ali je obećao suradnju. U Konak su na vijećanje o daljim aktivnostima pozvani kajmekami Muhamedbeg i Murad-beg, ali rasprave i pregovori nisu donijeli nikakav značajniji rezultat.

Uviđajući neusuglašenost vođa i lošu organizaciju pokreta, kao i činjenicu da je zbog ratnih djelovanja izostala očekivana pomoć iz drugih dijelova Bosne, muftija Karabeg je ponovo pokušao uvjeriti ustanike u apsurdnost otpora, čime je na sebe navukao njihov bijes. Događaji su dalje izmakli svakoj kontroli, što je kulminiralo krvoprolićem, odnosno ubistvom mutesarifa i njegovog zeta Ali-bega, potpukovnika Murat-bega, te mostarskog kadije i muftije Karabega. Potom je u Mostaru zavladalo bezvlašće, koje su iskoristile grupice rušilački nastrojenih ustanika, što je u gradu izazvalo paniku.

Prijelomna godina za Bosnu i Hercegovinu, 1878. kada Austrougarska dolazi na vlast, za tadašnje stanovništvo značila je godinu pometnje i općeg haosa. Vojska se želi boriti, a vlast ne dozvoljava otpor. Kao predstavnik islamske vlasti, muftija Karabeg ne želi donijeti odluku kojom bi u smrt odveo hiljade ljudi. Pobunjenici ga smatraju za izdajnika i vršeći stalni pritisak na njega da ili potpiše fetvu kojom prepušta Bosnu bez borbe ili da odobri pobunu, smišljaju kako da ga uklone. Sve njegove dvojbe bivaju uzaludnim, jer niti jedna odluka ne može biti ispravna. Muftija Karabeg je, naime, uvidio apsurdnost pokušaja organiziranja otpora s obzirom da su se o predaji BiH AustroUgarskoj dogovorile velike sile na Berlinskom kongresu. Karabega ubijaju skupa sa njegovom ženom i najboljim prijateljem, kadijom Kasimom.

Bez obzira na sve estetske nedostatke ovog dramskog teksta koje ističe književna kritika, mora se priznati da su ovaj dramski tekst, kao i sam roman kao njegovo izvorište, među najljepšim djelima bošnjačke književnosti, te da i roman i drama Karabeg predstavljaju prikaz trijumfa jezika (njegove intertekstualne uključenosti), ali i prikaz trijumfa samog lika Karabega koji biva žrtva vlastitih etički ispravnih stavova.

Uloga Karabega je jedna od najuvjerljivijih i najtransparentnijih $u$ cjelokupnom bosanskohercegovačkom dramskom stvaralaštvu, što se tiče monoloških dionica i najsnažnije emocije u predstavi su upravo u 
scenama u kojima se dvojba i dilema odvijaju u njemu samome. Izdati fetvu ili je ne izdati, postupiti po nalogu svoje savjesti ili se prepustiti zahtjevima razularene rulje.

Ibrišimović je u sklopu svog historijskog dramskog opusa obradio i lik čuvenog Huseina-kapetana Gradaščevića. Ova osebujna ličnost predstavlja neiscrpnu inspiraciju za većinu bošnjačkih umjetnika i nije nikakvo čudo, da je ona posebno aktualna u oblasti dramskog stvaralaštva, jer kako je to izjavio sam Nedžad Ibrišimović da je kod "Zmaja od Bosne" sam naslov dramatičan i da je s toga teško ostvariti čvrstu dramsku priču, pa je pisati dramsko djelo o ovom veličanstvenom čovjeku pravi istraživački izazov kojem ni Ibrišimović, kao odličan poznavalac bosanske prošlosti, nije odolio.

Da bi se u potpunosti percipirala dramska prikazanja o Gradaščeviću, neophodno je prije same percepcije dramskog djela proučiti lik i djelo ovog bosanskog junaka, te na taj način percipirane dramske dijelove uvlačiti u logički metatekst kroz simbiozu prošlosti (vremena prošlog) i sadašnjosti (vremena sadašnjeg). Zmaj od Bosne, hvalospjevna sintagma koju mu je dao bosanski narod, označava čovjeka po imenu Husein, rođenog 1802. godine u staroj kapetanskoj porodici Gradaščević, od oca Osmana i majke Đurđijanke po imenu Melekhana, koji je igrom slučaja, nakon smrti svoga brata (Murat-kapetana, kojeg je pogubio Dželal-paša), naslijedio jednu od najjačih i najznačajnijih kapetanija u Bosni.

$\mathrm{Na}$ osnovu različitih prijepisa iz vremena Osmanskog carstva (Hatt-i Hümayüna-carskih naredbi), te napisa Alekse Ivića, Boravak Huseinbega Gradaščevića u Osijeku od 5. jula do 4. oktobra 1832., u svojoj knjizi Pokret za autonomiju Bosne, Aličić nam daje gotovo dirljiv opis Husein-bega Gradaščevića, koji predstavlja nešto više od puke historijske biografije nacionalnog junaka. Husein-beg je odgajan kao plemić, kao neko ko će u budućnosti obavljati značajne državne funkcije, te mu je s toga otac omogućio privatne učitelje i vaspitače, od kojih je bio najpoznatiji sarajevski učenjak Mulla Mestvica, a također su ga podučavala i dva šejha, što je svakako utjecalo na izgradnju Huseinove pjesničke ličnosti i formiranje Huseina kao velikog vjernika koji je u potpunosti, ali ne fanatično poštovao islamske propise. Njegov najstariji brat Osman je napredovao do novoga paše i bio je veoma cijenjen u vojnoj hijerarhiji Osmanskog carstva, te je u vrijeme 
"Pokreta" ima velike probleme zbog svoga brata. Nakon što Husein postaje kapetan, uskoro se proslavlja, kao najutjecajniji i najmoćniji čovjek u cijeloj Bosni, a pri tome ne smijemo izgubiti iz vida da njegova kapetanija u tom trenutku slabljenja moći Osmanskog carstva zauzima jedno od strateški najvažnijih položaja, jer graniči i prema Srbiji i prema Austriji. U tom smislu je i zasnovan dramski sukob, na relaciji Austrougarska-Srbija-Osmansko carstvo, koji dirigira političku situaciju u Bosni.

U biografiji Zmaja od Bosne, nužno je spomenuti i fra. Iliju Starčevića, koji je također jedan od omiljenih likova u dramatizaciji prošlosti Bosne, te sačuvane dokumente koji svjedoče da je Husein svojevoljno dao dopuštenje Starčeviću da se sagrade samostan i katolička crkva u Tolisi. Međutim, bez obzira na prevaziđeni pozitivistički biografski pristup nekom književnom djelu, neosporna je činjenica da je pri analizi i ove i ostalih drama koje su posvećena Zmaju od Bosne, nužno, ali i zanimljivo povući paralele između stvarnosti i fikcije, a sve s ciljem da olakšamo percepciju univerzalne umjetničke problematike koju nam nameću ova drama inspirirana vremenom prve polovine 19. st. i svim onim događajima na uzavreloj političkoj sceni koji su od Huseinakapetana gradačačkog stvorili mitskog Zmaja od Bosne.

Kao vrijeme radnje Ibrišimović uzima konkretni historijski okvir, tridesete godine XIX vijeka, te se prikazuje tragičnu sudbinu Huseinbega Gradaščevića, kao čovjeka koji je razapet između životnih kontradiktornosti u koje biva uvučen kao tragična žrtva političkih igara koje oduvijek opkoljavaju Bosnu. Husein je rastrgan između želja i mogućnosti, između moći i nužnosti pokoravanja višim silama, između nužnosti poltronstva vlasti i bezgranične slobode.

Ibrišimović na vješt način, kreirajući lik koji živi svojevrsnu antonimiju surovih balkanskih prilika u prvim decenijama 19. st. uspijeva problematizirati univerzalne teme o ljudskoj krivici, moralnoj ispravnosti čovjekovih odluka i postupaka u kriznim trenucima historije (života), dihotomija čistih i prljavih ruku, o smislu ljudskog života u tamnom vilajetu. Ova drama nije inspirirana samo historijom, već i postojećim dramama Zmaj od Bosne, Hamida Šahinovića-Ekrema i Ahmeda Muradbegovića. Ova je drama pokazala da historijska događanja mogu maštovitom dramatičaru da posluže za stvaranje jedne nove vizije vremena prošlog $i$ vremena sadašnjeg u smislu 
premošćivanja vremena, kada se historijom problematizira sadašnjost. Ako posmatramo Šahinovićevog Zmaja od Bosne, možemo zaključiti da on, ali i njegov lik vrijeme posmatraju iz vizure svoga vremena (austrougarska okupacija) i za njega je Husein-beg prvenstveno borac protiv svih tlačitelja slobode, te na osnovu idealiziranja lika Huseninbega stvara sliku bosanskoga begovata. Sa druge strane Muradbegović je tragičnu sudbinu Husein-bega sagledao kroz okvire porodičnointimnog odnosa, kroz borbu Husein bega (probošnjački orijentiranog) sa bratom Osmanom (proosmanlijski orijentiranim), što je uvjetovalo izgubljenost njihove majke Đule.

Ibrišimović je potpuno izmijenio i strukturu i temu i likove, on je odbacio tendencioznosti i "državotvornosti" te pobunu glavnog lika problematizirao filozofski, kao odnos pojedinca i vlasti, slobode i neslobode, prava da se misli drugačije nego što misle silnici, ali i nemoć da se san o slobodi ostvari, osim u vlastitoj smrti, ili, ono najstrašnije, u izdaji samoga sebe, ulizivanju vlasti, pokajničkom priznanju svojih zabluda i molbi za oprost i milost.

Ibrišimović koristi postupak oneobičavanja i udaljuje se od historijske faktografije (posavski fratri). Tako je on iskomponirao i sliku vlasti, zamislivši da sve silnike, od Ali Dželaludina do Sultana tumači samo jedan glumac. To je vješta konstrukcija simboličke slike vlasti, koja nam pokazuje, da je vlast, bez obzira na ime i titulu, uvijek ista: bezglava, sa dvije glave, gnjecava, prevrtljiva i osvetoljubljiva, strašna kada se sveti i još strašnija kada prašta.

Njegov Zmaj od Bosne predstavlja modernu dramu isprepletenu od različitih stilskih elementa, tako da $u$ njoj možemo naći $i$ neoekspresionističke stilske zahvate iz fakcije $u$ fikciju, ali i dosta elemenata farse, pa i grotesknih elemenata koji su tipični za drame apsurda. Ono što najviše ovaj dramski tekst razlikuje od svih ostalih dramskih tekstova koji su posvećeni Huseinu-kapetanu Gradaščeviću je svakako doživljaj samoga glavnoga junaka, jer to više nije romantični doživljaj i zanos kojem je jedini zadatak da idealizira i veliča Huseina kao nacionalnog heroja, nego je to više drama dekonstriuranja i demitomanizacije jednog nacionalnog heroja, koji to odista jeste bio, ali je pored toga bio i samo čovjek sa svim svojim vrlinama, manama i prijelomima. 
Upravo zbog te činjenice profesorica Muzaferija ovu dramu determinira kao dramski tekst koji više nije drama povijesti, nego on prerasta $u$ povijesnu dramu. Ovakva dramska determinacija se može objasniti upravo tom činjenicom da ona tematizira sve ono što je Gradaščević preživio, a ne ono zbog čega je Gradaščević to preživio i samim tim pristupom se u startu odbija klasična idealizacija historijskog dramskog lika u sklopu nacionalromantizma.

O tome profesorica Muzaferija kaže: "I baš u tom sagledavanju načina podnošenja uspona i pada, u upozorenju na njegovu brzu slavu $i$ još brže suočenje sa patnjom velikih, sadržano je univerzalno značenje Ibrišimovićevog dramskog junaka. Njegova vertikala spoznaje samoga sebe odvija se na fonu stvarnih historijskih zbivanja, koja metodom analitičke drame ulaze u strukturu, kap po kap, čineći njen "prednji plan", dok se u "pozadini" uspostavlja parabola iz prošlosti za sadašnjost i postaje svevremena. ${ }^{\prime \prime 9}$

Dakle, upravo ta metoda da je u prvom dramskom planu istaknut junak koji spoznaje sama sebe $\mathrm{i} u$ toj spoznaji biva poražen je ona konstruktivna metoda koja je Ibrišimovića spasila od opasne, ali i umilne zamke da idealizira svoga dramskog junaka, pa tek u drugom dramskom planu razrađuje historijski okvir koji determinira njegovog junaka. Ovakva paralelizacija općeljudskog psihološkog sazrijevanja, koje podrazumijeva uspone i padove u determinaciji sa konkretnim historijskim vremenom, čini to vrijeme sveobuhvatnim i univerzalnim.

Husein munjevitom brzino prelazi trnoviti put, od kapetana pa sve do vezira, ali upravo ga taj njegov uspjeh na kraju i košta glave, jer on kao pobunjenik protiv sultana mora da bude nečasno uklonjen, bez obzira na motive koji ga pokreću, pa bio to i vlastiti patriotizam. Šahinović i Muradbegović su svoje drame završili na Zlom stupu, izgubljenom bitkom, a za razliku od njih, Ibrišimović radnju nastavlja dalje, on pomno prati Huseinov tragični put u samu smrt, pa prenosi dramsku radnju u: Osijek, Zemun, Beograd i Carigrad.

To su upravo najtragičnije slike Huseinovog života, jer svi počinju da ga odbacuju i da "peru ruke" od bune, te da ga kao žrtveno janje guraju

\footnotetext{
${ }^{9}$ Gordana Muzaferija, Činiti za teatar, Centar za kulturu i obrazovanje, Tešanj, 2004., str. 118.
} 
prema Carigradu/sultanu/smrti. Ovakav dramski zaokret je tipičan za dramu vlasti još od antike pa do danas. Dramski junak kasnije i sam okrvavljuje ruke, postajući tako žigosan kao neodvojivi dio vlasti i dio politike. U svom trnovitom putu ka vrhu, Husein se i sam na momente pretvara u tipičnog vlastodršca i naređuje smrtnu kaznu za sve one koji neće da mu se pokore... postaje isti kao oni protiv kojih se i sam bori, i biva užasnut sviješću o svojim krvavim rukama. Ova strašna spoznaja je simbolično prezentirana kada Husein preko krvave halje navlači vezirsko ruho i u tom trenutku se približava nadohvat smrti, te postaje gnjecav kao ilovača, baš kao i omražena i trula utvara Dželaludin-paše.

"ĐULA: Paša moj! Huseine! Sav si krvav!

HUSEIN: Kaznio sam Selmanovića iz Teslidže zato što je obrekao sveti boj kod Kačanika!

ĐULA: Skini tu halju sa sebe, eto te k'o kakva utvara! Obuci ovo ruho vezirsko što si dao da ti ga skroji tvoj terizbaša nad terazijama! Skini to sa sebe! Nisi derviš!

HUSEIN: (Husein preko one krvave halje oblači bogato vezirsko ruho pri tome mu pomaže Fidahić) $)^{\prime 10}$

Husein tako i sam postaje žrtva nepobjedive vlasti i žeđi za vlašću koja ga izjeda kao individualca slobodne misli i tjera ga da i sam okrvavi ruke. Cijela dramska radnja je raščerečena između pobune i slijepe vjere u pobjedu, te kazne za neposluh i degeneracije pod utjecajem moći i vlasti, tako da radnja drame protiče na razini svijesti. Husein predstavlja klasičnog tragičnog junaka koji se kao individualac otvoreno sukobljava sa izaslanicima centrale moći (vlasti) i zbog toga biva potpuno uništen. Taj pokušaj da se općoj volji nadredi svoja pojedinačna, je ono što još od antike pokreće tragične dramske junake.

Đula, žena Huseinova, ona je kao i ledi Magbet po pitanju muževog slavoljublja i častoljublja, ali gaji i vlastite planove i ambicije, te želi da ga vidi na samom vrhu vlasti. Međutim, u trenucima pada i poraza, kada je došlo do sudbonosnog pitanja života i smrti, ona pokazuje da je iza svega toga, samo obična žena koja ga silno voli.

${ }^{10}$ Nedžad Ibrišimović, Zmaj od Bosne, Drame, "Veselin Masleša", Sarajevo, 1988, Str. 37.-38. 
"Uvijek sam žarko željela da budeš nešto više od drugih ljudi, a sad bih tako željela da si niko i ništa... Sultan ti nudi oproštaj, čak đeneralska odličja, nemoj se gorditi, što ćeš mi mrtav, mrtav mi ne trebaš..."11

U zadnjim scenama Ibrišimović uvodi nekoliko novih i izuzetno zanimljivih likova koji na neki način oživljavaju dramu i koji su iskorišteni da tragičnom Huseinovom padu i historijskom i ličnom daju notu filozofsko-poetske aure. Ovaj dramski tekst je prenapregnut sa akcijom i u momentima se moć začas okreće u potpunu bespomoćnost, ali se ona ujedno i dekonstruira kroz vječno definiranje vlasti i moći između egzistencijalne i moralne sfere postojanja. U onim momentima kada je Husein već okušao kako je to imati vlasti, ali i kako je to biti potpuno bespomoćan, on postavlja pravo filozofsko pitanje razapeto između iskonih potreba svakoga čovjeka, i onih egzistencijalnih i onih moralnih, kada se zagleda u svoju skicu koju je napravila Đulija fon Čerge.

"HUSEIN: (Uzme crtež) To sam ja! Sumnjao sam, strahovao, sad vidim! Samo sjena! Obris!

Samo blijeda sjena negdašnjeg Gradaščevića! Da puhnem bih se oduvao... Ja sam utvara! ...

Utvara! ... Mene gotovo nema...!

ĐULIJA: Odmah mi vratite moj skicen-blok! Odmah! I ne duvajte u to! HUSEIN: Rukom da mahnem bih te istro, Husein-kapetane!..." 12

Ova historijska drama funkcionira kao drama identiteta, ali je Ibrišimović uspio postići maksimalnu koncentraciju na univerzalno, obuhvativši tako opću ljudsku dramu u kojoj su ljudi izgubljeni i uplašeni samih sebe, jer nisu ništa drugo nego svoja vlastita sjena. Najpotresnija dramska scena je upravo ona u kojoj je Husein najviše svoj i najviše nostalgični pjesnik, to je onaj trenutak kada on ljubomorno čuva od sultana svoje utiske sa putovanja od Beograda do Carigrada, kao da su ti utisci najveća državna tajna, jer on je u tom trenutku smrtno bolestan i već svjestan da je spoznao misteriju ljudskog

\footnotetext{
11 Ibid., str. 71.

12 Nedžad Ibrišimović, Zmaj od Bosne, Drame, "Veselin Masleša", Sarajevo, 1988, str. 71 .
} 
postojanja, koja mu se otkriva u zimskim pejzažima. On spoznaje surovu i hladnu odvojenost svijeta od čovjeka, te se miri sa činjenicom da je čovjek uvijek stranac u vlastitom svijetu. Ono što je najviše bolno za Huseina je prihvaćanje spoznaje da je Bosna zemlja koju je zauvijek napustio i da ona od tog trena za njega može postojati samo u emanaciji njegovih sjećanja, te upravo zato ljubomorno čuva svoje utiske sa putovanja kroz zimske pejzaže, jer je to jedino od Bosne što mu sultan ne može oduzeti.

'SULTAN: Kako je bilo na putu?

HUSEIN: Dobro...

SULTAN: Pravo reci...

HUSEIN: Pravo...?

SULTAN: Jah.

HUSEIN: Žao mi reć'...

SULTAN: Šta?

HUSEIN: Snijeg, snijeg, snijeg sam gledao kako pada... Na drugo se nisam obazirao.

SULTAN: I to ti je bilo žao reći...? "13

Snježni pejzaž je za Huseina njegova Bosna koju on ljubomorno čuva samo za sebe. Upravo su kroz elemente Huseinovog nostalgičnog zanosa i vezani rijetki lirski odlomci ovog dramskog teksta, iako je cijela drama u oštrom ekspresionističkom tonu. Posebno je poetski imaginativna lirska metafora Bosne kao oslonca za njegovu dušu, jer on sumnja u sve, osim u Bosnu. Sama Bosna je jedna pjesma, jer on kaže da bi dao sve kada bi Bosna bila jedna kasida ili bar jedan gazel.

"HUSEIN: (Razotkriva je) I ovo me boli!... I ovo... na tebi... Uh, kako mene sve ovo boli! Nisam znao da bih dao sve što imam samo kad bi Bosna bila jedna kasida ili makar jedan gazel!

ĐULA: Cijela Bosna?

${ }^{13}$ Ibid., str. 53.-54. 
HUSEIN: Cijela Bosna i Hercegovina!"'14

Ovo je jedan od rijetkih primjera lirizima u ovom dramskom tekstu, a svi poetski elementi su kroz cijeli dramski tekst vezani za Bosnu. Međutim, cijela drama obiluje elementima ironijskog i grotesknog, što je posebno izraženo u zadnjoj sceni, jer Gradaščević svjesno gubi bitku sa ovim svijetom, iako ostaje dosljedan sebi, on razrješava svoje odnose sa ljudima i samim sobom, ali i postaje svjestan da ni na onom svijetu neće naći smiraj, jer i nad njegovim grobom lebde muka i dušmani, čime se ironizira i nada u smiraj na drugom svijetu koji ne predstavlja ništa drugo, do novi beskonačan okvir za neko novo stradanje i neku novu muku i tako u nedogled. Tako Husein ne nalazi smiraj ni u grobu, jer strepi za budućnost svoga sina Muhameda i upravo ovakav dramski rasplet najviše podsjeća na teatar apsurda i njegovu apokaliptičnu viziju svijeta.

"HUSEIN: Nisam toliko griješio! A ako jesam Allah će mi suditi! Ja više ništa ne mogu, ja umirem... Jedino mi reci: kad odem hoće li koja tegoba lebdjeti nad mojim grobom? Hoće li, kada umrem, moju muku zrak razrijediti... hoće li se dušmani na nju laktovima oslanjati, ne daj Bože, moga Muhameda pritiskati..."15

Ovakav dramski završetak najbolje potvrđuje Ibrišimovićev zaokret iz historijskih fakata u bogato univerzalno značenje, on se dakle kreće od Huseina kao konkretne historijske ličnosti koja se bori sa problematikom svoga vremena do Huseina kao čovjeka koji shvatabesmisao ljudske egzistencije i na taj način nam prezentuje književno-umjetničku istinu, kojaduboko zadire u unutarnje nezadovoljstvo suvremenog i svevremenog čovjeka.

Ovakva grandiozna historijska ličnost i njegova borba za nezavisnost Bosne i Hercegovine će postati jedna od najinspirativnijih tema na kojima su svoje književna djela gradili mnogi bošnjački autori, ali i historičari, čija djela o ovom bošnjačkom velikanu imaju i svojevrsnu dozu literarnosti.

\footnotetext{
${ }^{14}$ Nedžad Ibrišimović, Zmaj od Bosne, Drame, "Veselin Masleša", Sarajevo, 1988, str. 38.

15 Ibid., str. 57.
} 
Boja hrđe (1985.) je dramski tekst koji govori o vremenu prošlom u tamnom vilajetu koje je obilježeno hajdučijom i mrtvim glavama, ali je to vrijeme prošlo oslobođeno historijske konkretizacije i ono je neodređeno u tom smislu, međutim, najvjerovatnije se radi o sredini XIX vijeka. U ovom dramskom tekstu imamo košmaran tok dramske radnje i na neki lucidan način se u njemu miješaju realno i irealno, živi i mrtvi, te on obiluje elementima fantastike koji se prezentiraju u žanru farse.

Košmarnost dramske radnje je pomalo mutna i mračna, a ponekad i proizvoljna, pa je tako u njenom trajanju sve moguće, po uzoru na teatar apsurda, sve je dozvoljeno, čak i ono najlucidnije, međutim, ništa nije do kraja i cjelovito izvedeno, tako da sve ostaje nedorečeno i prema tome sklono različitim i beskonačnim tumačenjima. Svaka dramska situacija i svaki dramski lik su konstruirani kao varijabilni, neuhvatljivi i u vječnom kretanju, tako da nam se ponekad čini da se radi o drami neobičnih i lucidnih metafora koje kriju neka viša i misteriozna značenja, koja su istovremeno i pjesnička i filozofska, ali, na trenutke nam se čini i da je cjelokupan dramski tekst toliko fragmentaran da se osipa i raspada u nebuloznom košmaru dramskih i pjesničkih proizvoljnosti.

U dijalozima se najviše uočava utjecaj teatra apsurda i njegovih neobičnih dijaloga koje Ibrišimović iskorištava, te nam prezentira jako zanimljive dijaloške dionice u kojima se smjenjuju izuzetna ekspresivnost i misaonost, ali su uočljivi i gotovo nasilni pokušaja da se govornim iskazom ukaže na oneobičavanje određene situacije, likova ili odnosa među likovima, ne bi li se postigao odnos dramskog alogizma i apsurda, kao, na primjer, u razgovoru mrtvih glava Vuka Vujovića i harambaše Luke, dok otkinute i položene na zemlju posmatraju odnos između Ljube i Benjamina.

"VUK: Vidiš li...?

LUKA: I vidim i ne vidim...A ti?

VUK: I ja...

LUKA: Neka...

VUK: Ne velim...

LUKA: A uze li je...? 
VUK: Uzeh je.. Uze li je?

LUKA: Uzeh je.. Uze li je?

VUK: Uze... Uze li je?

LUKA: Uzeće...

VUK: Uzeće...?

$\boldsymbol{L} \boldsymbol{U K} \boldsymbol{A}:$ Uzeo je...

VUK: Uzeo...?

LUKA: I ja sam." 16

O tome Josip Lešić kaže: " Drama Boja hrđe više je nalik na dijalošku skicu, nego na cjelovito i do kraja smišljeno i izvedeno dramsko djelo: i zamka i put, lavirint iz koga se jedino Ibrišimović sam može izvući, iznoseći na čistinu sve ono autentično i osebujno što bi mogla da bude samo njegova , ali čista i precizno oblikovana, dramska poetika."17

Ova drama je izgrađena na odbljescima iskrivljenih ogledala. Na osnovu takve konstatacije možemo zaključiti da je ovaj dramski tekst jako kompleksan, iako se na prvi pogled čini jednostavnim po svojoj klasičnoj strukturi, ali on je izuzetno težak za definiranje i može se svrstati i u historijske i u političke i u moralizatorske drame, pa se čak može i povezati sa teatrom apsurda.

Po svom osnovnom tonu ona je jedna vrsta tragikomedije ili lakrdije, kako je to sam autor označio, međutim to nije toliko žanrovsko određenje, koliko je to jedan intelektualistička provokacija koju nam zadaju likovi ove drame, i kojom je Ibrišimović opsjednut u svim svojim djelima, a to je pitanje etike čovjekovog djelovanja koju samoanaliziraju njegovi likovi. Dakle, oni su, pored toga što su protagonisti samotkrivanja u smislu zapleta, i samoanalizatori na etičkom nivou svega onog što čine, tako da Ibrišimović ostaje pošteđen autorskih implikacija, i lakrdiju prepušta svojim likovima, koji su uveliko svjesni apsurda svoga postojanja koje je uvjetovano nemilosrdnim poigravanjem historijskih okolnosti nad kojima oni

\footnotetext{
${ }^{16}$ Nedžad Ibrišimović, Boja hrđe, Drame, "Veselin Masleša", Sarajevo, 1988, str. 109.

17 Lešić, Josip, Dramska književnost II, Institut za književnost/Svjetlost, Sarajevo, 1991., str. 215.
} 
nemaju nikakve moći. Kroz komične elemente polako izranja sve tragičnija slika apsurda čovjekovog života.

C. G. Jung je put pronalaska ne-dualiteta/jedinstva/identiteta definisao rečenicom :"Čovjek se treba odreći vlastitog Ega da dobije vlastito sebstvo ". Upravo na tom putu se nalaze svi Ibrišimovićevi likovi, jer, praktično, sve se svodi na otkrivanje jednog novog svijeta, koji je do sada ostajao neprimijećen zbog zbunjenosti duha odgojenog u ograničavajućem dualizmu. Ili, drugim riječima rečeno, svi njegovi junaci proživljavaju onaj "ibrišimovićevski" trenutak u kojem se ostvaruje individualna svijest koja i poslije smrti ostaje indvidualna, ali koja tada egzistira u skladnosti sa univerzalnom kosmičkom sviješću. Svi ti likovi mogu postojati i ne postojati istovremeno. Baš kao po principima suvremene fizike, koja također više ne razdvaja promatrača i promatranog, već oni nužno tvore cjelovit sistem. Da bi se prihvatio takav paradoks, potrebno je odreći se iluzije da postoji samo jedno rješenje problema. To bi značilo da se u odnosu Ja - Drugi treba izaći iz sebe u smjeru Drugog.

Prošlost je kod Ibrišimovića Njegova koncepcija vremena svakako je pod uticajem Bergsonove filozofije intuicionizma, jer on na osnovu nje pronalazi izlaz iz bezizlazne jalovosti i prolaznosti života u otkriću činjenice da ljudska podsvijest skladišti u sebi sve impresije, pa je naizgled izgubljeno vrijeme pohranjeno u svojevrsnu neizbrisivu memoriju i dostupno je u nesvjesnom segmentu bića. Međutim, prošlo vrijeme nije zauvijek mrtvo, a ni umrtvljeno, nego se može prizvati na razinu svijesti i izraza nehotičnim, osjetilnim sjećanjem tijela, koje pamti ne samo zbivanja nego i minule porive i emocije.

Vrijeme zabilježeno u Ibrišimovićevom stvaralaštvu je u konstantnoj promjeni, tako da i događaji iz prošlosti i iz sadašnjosti imaju jednaku realnost. Tako se, slijedeći njegovu poetiku, moramo okrenuti neposrednim datostima svijesti: vrijeme nije nešto poput točka, već je kontinuirano i protežno, sastavljeno od dimenzija: prošlost, sadašnjost i budućnost. Ispitujući činjenice svijesti, on ukazuje da one nisu homogene već da se svijest sastoji od heterogenih međusobno prožimajućih momenata koji konstituiraju jedno trajanje. Vrijeme je stoga odbljesak trajne svijesti te je u svojoj biti trajanje, proces $\mathrm{u}$ neprestanom obogaćivanju, baš kao što su i njegova književna djela trajno obogatila bošnjačku književnost. 


\section{Literatura:}

1. Aličić, Ahmed, Pokret za autonomiju Bosne od 1831. do 1832. godine, Orijentalni institut u Sarajevu, Sarajevo, 1996.

2. Ibrišimović, Nežad, Ugursuz, Karabeg, Zmaj od Bosne, Boja Hrđe, Narodno Pozorište Tuzla, rukopisi.

3. Kazaz, Enver, Bošnjački roman XX vijeka, Naklada ZORO, ZagrebSarajevo, 2004.

4. Kreševljaković, Hamdija, Kapetanije u BiH, Svjetlost, Sarajevo, 1980.

5. Lešić, Josip, Dramska književnost II, Institut za književnost/Svjetlost, Sarajevo, 1991.

6. Lešić, Josip, Savremena drama i pozorište u Bosni i Hercegovini, Sterijino pozorje, Novi Sad, 1984.

7. Lešić, Josip, Savremena dramska književnost u Bosni i Hercegovini (tema i struktura), U: Drame, Savremena književnost naroda i narodnosti BiH u 50 knjiga, Svjetlost, Sarajevo, 1985.

8. Lešić, Josip, Vrijeme prošlo - vrijeme sadašnje, Scena, 1970, br. 1-2.

9. Lešić, Zdenko, Nova čitanja - Poststrukturalistička čitanka, Buybook, Sarajevo, 2003.

10. Lešić, Zdenko, Teorija drame kroz stoljeća, Svjetlost, Sarajevo, 1977.

11. Lešić, Zdenko, Kapidžić-Osmanagić, Hanifa, Katnić-Bakaršić, Marina i Kulenović, Tvrtko, Zbornik radova grupe autora/autorica, Suvremena tumačenja književnosti, Sarajevo Publishing, Sarajevo, 2007.

12. Lukić, Sveta, Savremena jugoslovenska drama, Prosveta, Beograd, 1968.

13. Melchinger, Siegfried, Povijest političkog kazališta, Grafički zavod Hrvatske, Zagreb, 1989.

14. Miočinović Mirjana, Moderna teorija drame, Nolit, Beograd, 1981.

15. Muzaferija, Gordana, Rizvanbegović, Fahrudin, Vujanović Vojislav, Antologija bošnjačke drame XX vijeka, Alef, Sarajevo, 2000.

16. Muzaferija, Gordana, „Bosanskohercegovačka drama ili Dijalog s vremenom", u: Činiti za teatar, Centar za kulturu i obrazovanje, Tešanj, 2004.

17. Muzaferija, Gordana, Bošnjačka književnost u književnoj kritici, Novija književnost - Drama, Alef, Sarajevo, 1998. 
18. Muzaferija, Gordana, „Između historije i savremenosti (bosanskohercegovačka drama 1967-1977)“, u: Činiti za teatar, Centar za kulturu i obrazovanje, Tešanj, 2004.

19. Pfister, Manfred, Drama - teorija i analiza, Hrvatski centar ITI, Zagreb, 1998.

20. Selenić, Slobodan, Dramski pravci XX veka, Umetnička akademija u Beogradu, Beograd, 1971.

21. Pavis, Patrice, Pojmovnik teatra, Izdanja antibarbarus, Zagreb, 2004.

22. Kraj utopije i pozorišta - kritike i eseji (1985-2000), Otkrovenje, Beograd, Sterijino pozorje, Novi Sad, 2000. 
Amra Memic, $\mathrm{PhD}$

\section{NEDZAD IBRISIMOVIC'S DRAMA WORK AS A REFLECTION OF FLASHES FROM VARIABLE UNIVERSAL HUMAN PAST}

\section{Abstract}

Nedzad Ibrisimovic's drama work is bounded and determined by history as an eternal inspiration that draws its sources from the rich and fertile Bosniak community. It is important, even essential, to mention that his dramatic texts are woven on topics that he has already artisticly touched and elaborated in his comprehensive and novelistic narrative work. For Ibrisimovic, history is not defined through a traditional definition whose starting point is always founded on a significant historical event or a significant historical figure, and is therefore doomed to a retrospective point of view.

In contrast, Ibrisimovic defines history in the way it was established by Nietzsche, and later many accepted this definition of history as a variable collects of the history of mentality, where history must necessarily be viewed as a "live" creative tissue, dual of present and the future and because it is important to know this psychological side of history, as an explicit indicator of "history from below'.

His concept of history, which explicitly shaped his creative work, is such that he is always trying to find what is universal through existential reflections of variable past, to find that that what determines humankind since its existence like an incurable curse, and so, again and again, he is looking for new in the old; wants to realize what is known; he is seeking individuality in humanity, which is an essential goal of every genuine artistic creativity.

Keywords: Nedzad Ibrisimovic, history, stream of consciousness, floating past, time, universally human, foreboding, Mufti Karabeg, Hussein Bey Gradascevic, Dragon of Bosnia, Color of Rust, Bosniak literature, drama literature, theater of the absurd, historical drama. 
الدكتورة المساعدة عَمرة مَميتش' - مَش

إبداع نجاد إبريشيموفيتش الدرامي بوصفه انعكاساً لومضة الماضي الإنساني العام المتغير

\section{الخلاصة}

عمل نجاد إبريشيموفيتش الدرامي محدد بالتاريخ باعتباره الإلهام الخالد الذي

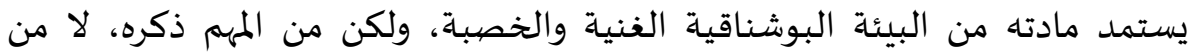

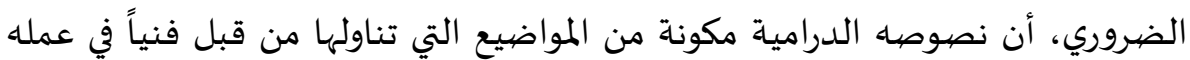

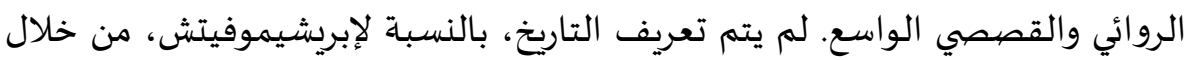

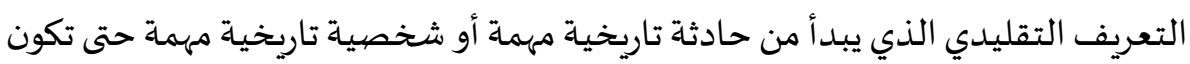

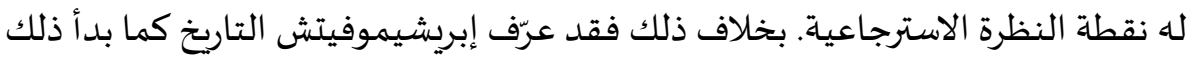

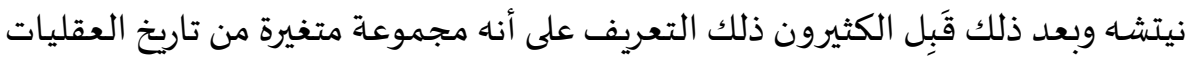

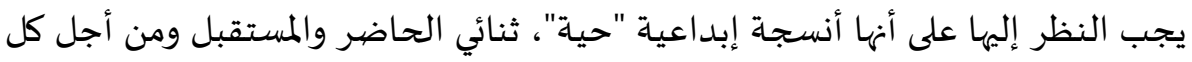

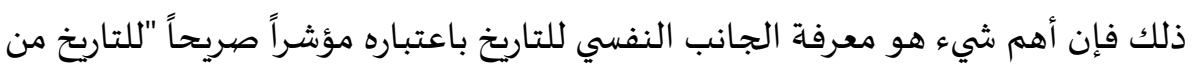

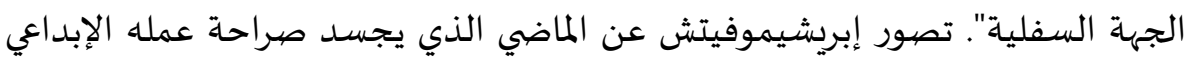

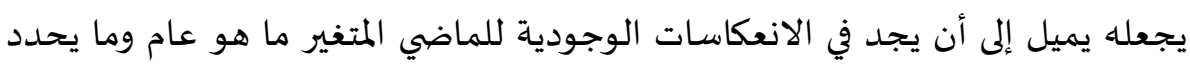

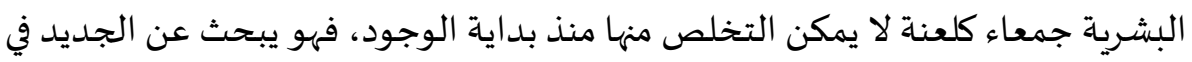

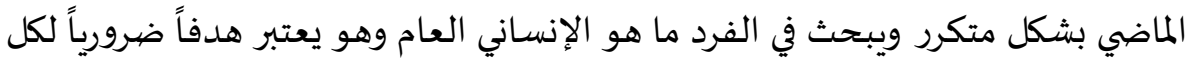

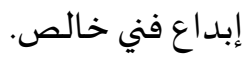

الكلمات الرئيسة: نجاد إبريشيموفيتش، التاريخ، الماضي المتغير، الوقت، الإنساني

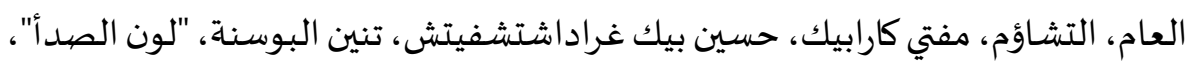

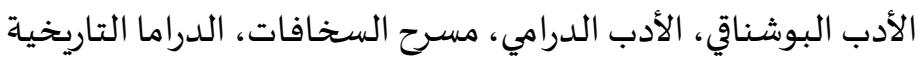

